\title{
Analisis Pengaruh Loyalitas dan Komitmen Organisasi terhadap Kinerja Karyawan
}

\author{
Ahmad Suhardi \\ Universitas Muhammadiyah Palopo \\ ahmadsuardi@umpalopo.ac.id \\ Ismilasari \\ Universitas Muhammadiyah Palopo \\ ismilasari@gmail.com \\ Jumawan Jasman \\ Universitas Muhammadiyah Palopo \\ jumawan@umpalopo.ac.id
}

\begin{abstract}
Abstrak
Kinerja merupkan perwujudan kerja yang dilakukan karyawan dengan tujuan sebagai dasar untuk menilai karyawan pada sebuah organisasi perusahaan. Loyalitas dan komitmen organisasi merupakan faktor utama yang dimiliki oleh karyawan dalam mempertahanakan kinerja. Komitmen organisasi timbul karna adanya ikatan emosional dan kepercayaan antara karyawan dengan organisasi. Sementara loyalitas merupakan kesetiaan yang disertai ide, gagasan untuk mencapai kinerja dalam sebuah organisasi perusahaan. Penelitian ini bertujuan untuk mengetahui pengaruh loyalitas dan komitmen organisasi terhadap kinerja karyawan baik secara parsial maupun secara simultan, ketiga variabel tersebut diukur berdasarkan indikator pengukuran variabel yang berseumber pada penelitian sebelumnya. Penentuan jumlah sampel dalam penelitian ini diambil berdasarkan metode sensus yaitu seluruh populasi berjumlah 35 karyawan, jumlah ini sekaligus dijadikan sebagai sampel penelitian. Metode analisis yang digunakan yaitu analisis regresi linier berganda. Berdasarkan hasil analisis bahwa untuk variabel loyalitas dan komitmen organisasi secara simultan berpengaruh terhadap kinerja karyawan. Secara parsial loyalitas berpengaruh secara signifikan terhadap kinerja karyawan sedangkan komitmen organisasi tidak berpengaruh signifikan terhadap kinerja karyawan. Berdasarkan nilai koefisien determinasi yang dihasilkan yaitu sebesar 16,6\% menandakan bahwa model penelitian masih perlu untuk dikembangkan lagi oleh peneliti selanjutnya. Disarankan pada penelitian selanjutnya untuk mengembangkan model persamaan dengan menambahkan variabel lain yang diprediksi dapat berpengaruh terhadap kinerja yaitu insentif, dan pelatihan.

Kata Kunci Loyalitas, Komitmen Organisasi, Kinerja Karyawan
\end{abstract}

\section{PENDAHULUAN}

Perusahaan akan menuntut karyawannya untuk bekerja dengan baik agar dapat bersaing dalam dunia bisnis saat ini. Pada dasarnya, perusahaan tidak hanya membutuhkan karyawan yang mampu dan terampil, namun perusahaan sangat membutuhkan karyawan yang bisa bekerja lebih giat dan mempunyai keinginan untuk mencapai hasil yang optimal sesuai dengan tujuan perusahaan. Dukungan perusahaan terhadap peningkatan kinerja karyawan menjadi hal penting untuk diperhatikan. Kinerja merupakan pencapaian suatu hasil kerja seseorang dalam melaksanakan tugas-tugas yang dibebankan kepadanya yang didasarkan atas kecakapan, pengalaman dan kesungguhan serta waktu (Muis, Jufrizen, \& Fahmi, 2018). Banyak hal yang mendukung bagi sumber daya manusia untuk memiliki kualitas dan kinerja yang baik, salah satunya adalah komitmen dari karyawan yang bersangkutan terhadap perusahaan tempatnya 
berada. Komitmen organisasional merupakan suatu ikatan emosional antara karyawan dengan organisasi yang timbul karena adanya kepercayaan, kemauan untuk mencapai suatu tujuan serta keinginan untuk mempertahankan keanggotaan diri sebagai bagian dari organisasi dan hal tersebut yang menjadikan karyawan akan tetap bertahan dalam suatu organisasi baik dalam kondisi menyenangkan maupun tidak.

Karyawan yang mempunyai komitmen yang kuat akan tetap konsisten tinggal pada organisasinya (Nasution, 2017). Kuatnya komitmen dari karyawan pada perusahaan turut menjadi penentu bagaimana sifat dan tingkah laku karyawan tersebut selama berada dalam perusahaan. Komitmen organisasional mendorong karyawan untuk mempertahankan pekerjaannya dan menunjukkan hasil yang seharusnya. Karyawan yang memiliki komitmen yang tinggi terhadap perusahaan cenderung akan menunjukkan kualitas yang baik, lebih totalitas dalam bekerja dan tingkat pergantian karyawan terhadap perusahaan pun renda. Adapun upaya yang dilakukan untuk meningkatkan kinerja karyawan melalui komitmen pada pekerjaan yaitu salah satunya dengan mempertahankan karyawan yang berpotensi disetiap bagian dan jabatan, selain adanyan komitmen organisasi yang tinggi, karyawan akan melibatkan diri unruk menyelesaikan semua tugas dan tanggung jawab. Membangun komitmen organisasi menjadi lebih bermanfaat, karena dapat menjadikan perusahaan sebagai tempat yang menenangkan untuk bekerja.

Selain itu faktor loyalitas dipandang sebagai salah satu yang berpengaruh terhadap kinerja karyawan. Loyalitas merupakan kondisi yang mengikat antara karyawan dengan perusahaannya, karena loyalitas bukan hanya kesetiaan yang tercermin dari seberapa lama seseorang berkerja di dalam organisasi perusahaan, namun dapat dilihat juga dari seberapa besar pikiran, ide, gagasan, serta kinerjanya tercurah sepenuhnya kepada perusahaan itu (Onsardi, 2018). Karyawan yang miliki loyalitas pada dasarnya akan memiliki ketaatan pada peraturan. Ketaatan ini didasari pada kesadaran yang dimiliki oleh karyawan bahwa peraturan yang dibuat perusahaan disusun untuk membantu mengorganisir kelancaran jalannya pelaksanan kerja. Kondisi ini menjadikan karyawan mampu bersikap baik dan taat tanpa adanya rasa keterpaksaan atau takut terhadap sanksi yang akan diterima apabila melanggar peraturan tersebut. Karyawan yang mempunyai loyalitas kerja yang baik maka akan memiliki hubungan dan ligkungan yang harmonis dengan rekan kerja dan pimpinan.

Beberapa hasil penelitian sebelumnya yang mengkaji tentang pengaruh loyalitas dan komitmen organisasi terhadap kinerja karyawan menghasilkan temuan yang berbeda atau masih terdapat gap hasil penelitian. Penelitian yang dilakukan oleh Muis, Jufrizen, Fahmi (2018); Nathania (2018); Kosasih (2014), menghasilkan informasi temuan bahwa komitmen organisasi berpengaruh positif signifikan terhadap kinerja karyawan. Berbeda dengan hasil temuan penelitian yang dilakukan oleh Arizona, Riniwati, \& Harahap. (2013), bahwa Secara parsial komitmen organisasional tidak mempunyai pengaruh yang signifikan terhadap kinerja pegawai. Hasil temuan penelitian yang sama dilakukan oleh Subejo, Troena, Thoyib, Aisjah (2013) menunjukan bahwa secara parsial komitmen organisasional tidak mempunyai pengaruh yang signifikan terhadap kinerja. Selanjutnya penelitian yang dilakukan oleh Saputra, Bagia dan Yulianthini (2016); Ariyani, Aini, \& Tjahjono (2016); Mamesah, Kawet \& Lengkong (2016), bahwa loyalitas karyawan berpengaruh positif signifikan terhadap kinerja karyawan. Berbeda dengan hasil temuan yang dilakukan oleh Tamba, Pio, \& Sambul (2018); Lumingkewas, Adolfina, \& Uhing (2019) bahwa tidak terdapat pengaruh signifikan antara loyalitas karyawan terhadap kinerja karyawan. Berdasarakan pada uraian latar belakang dan adanya research gap, maka tujuan penelitian ini yaitu pertama, untuk menganalisis pengaruh komitmen organisasi terhadap kinerja karyawan, kedua, untuk menganalisis pengaruh loyalitas karyawan terhadap kinerja karyawan.

\section{LANDASAN TEORI}

\section{Kinerja Karyawan}

Perusahaan akan menuntut karyawannya untuk bekerja dengan baik agar dapat bersaing dalam dunia bisnis saat ini. Pada dasarnya, perusahaan tidak hanya membutuhkan karyawan yang 
mampu dan terampil, namun perusahaan sangat membutuhkan karyawan yang bisa bekerja lebih giat dan mempunyai keinginan untuk mencapai hasil yang optimal sesuai dengan tujuan perusahaan. Dukungan perusahaan terhadap peningkatan kinerja karyawan menjadi hal penting untuk diperhatikan. Kinerja merupakan pencapaian suatu hasil kerja seseorang dalam melaksanakan tugas-tugas yang dibebankan kepadanya yang didasarkan atas kecakapan, pengalaman dan kesungguhan serta waktu (Muis, Jufrizen, \& Fahmi, 2018).

Banyak hal yang mendukung bagi sumber daya manusia untuk memiliki kualitas dan kinerja yang baik, salah satunya adalah komitmen dari karyawan yang bersangkutan terhadap perusahaan tempatnya berada. Komitmen organisasional merupakan suatu ikatan emosional antara karyawan dengan organisasi yang timbul karena adanya kepercayaan, kemauan untuk mencapai suatu tujuan serta keinginan untuk mempertahankan keanggotaan diri sebagai bagian dari organisasi dan hal tersebut yang menjadikan karyawan akan tetap bertahan dalam suatu organisasi baik dalam kondisi menyenangkan maupun tidak.

Karyawan yang mempunyai komitmen yang kuat akan tetap konsisten tinggal pada organisasinya (Nasution, 2017). Kuatnya komitmen dari karyawan pada perusahaan turut menjadi penentu bagaimana sifat dan tingkah laku karyawan tersebut selama berada dalam perusahaan. Komitmen organisasional mendorong karyawan untuk mempertahankan pekerjaannya dan menunjukkan hasil yang seharusnya. Karyawan yang memiliki komitmen yang tinggi terhadap perusahaan cenderung akan menunjukkan kualitas yang baik, lebih totalitas dalam bekerja dan tingkat pergantian karyawan terhadap perusahaan pun renda. Adapun upaya yang dilakukan untuk meningkatkan kinerja karyawan melalui komitmen pada pekerjaan yaitu salah satunya dengan mempertahankan karyawan yang berpotensi disetiap bagian dan jabatan, selain adanyan komitmen organisasi yang tinggi, karyawan akan melibatkan diri unruk menyelesaikan semua tugas dan tanggung jawab. Membangun komitmen organisasi menjadi lebih bermanfaat, karena dapat menjadikan perusahaan sebagai tempat yang menenangkan untuk bekerja. Selain itu faktor loyalitas dipandang sebagai salah satu yang berpengaruh terhadap kinerja karyawan. Loyalitas merupakan kondisi yang mengikat antara karyawan dengan perusahaannya, karena loyalitas bukan hanya kesetiaan yang tercermin dari seberapa lama seseorang berkerja di dalam organisasi perusahaan, namun dapat dilihat juga dari seberapa besar pikiran, ide, gagasan, serta kinerjanya tercurah sepenuhnya kepada perusahaan itu (Onsardi, 2018). Karyawan yang miliki loyalitas pada dasarnya akan memiliki ketaatan pada peraturan. Ketaatan ini didasari pada kesadaran yang dimiliki oleh karyawan bahwa peraturan yang dibuat perusahaan disusun untuk membantu mengorganisir kelancaran jalannya pelaksanan kerja. Kondisi ini menjadikan karyawan mampu bersikap baik dan taat tanpa adanya rasa keterpaksaan atau takut terhadap sanksi yang akan diterima apabila melanggar peraturan tersebut. Karyawan yang mempunyai loyalitas kerja yang baik maka akan memiliki hubungan dan ligkungan yang harmonis dengan rekan kerja dan pimpinan.

\section{Loyalitas}

Loyalitas kerja atau kesetiaan merupakan salah satu unsur yang digunakan dalam penilaian karyawan yang mencakup kesetiaan terhadap pekerjaannya, jabatannya dan organisasi (Hasibuan, 2002). Kesetian ini dicerminkan oleh kesediaan karyawan menjaga dan membela organisasi didalam maupun diluar pekerjaan dari gangguan orang yang tidak bertanggung-jawab. Loyalitas karyawan dapat dilihat dari kinerja karyawan. Jika kinerja karyawan baik, taat pada peraturan dan optimal maka dapat dinilai karyawan memiliki loyalitas tinggi terhadap perusahaan, bila karyawan tidak dapat bekerja dengan baik dan optimal berarti karyawan tidak loyal terhadap perusahaan.

Faktor-faktor yang mempegaruhi loyalitas menurut (Saydam, 2000) adalah:

1. Ketaatan atau kepatuhan.

Ketaatan atau kepatuhan yaitu kesanggupan seorang karyawan untuk mentaati segala peraturan kedinasan yang berlaku dan mentaati perintah dinas yang diberikan atasan yang berwenang, serta sanggup tidak melanggar larangan yang ditentukan. 
2. Bertanggung jawab.

Bertanggung jawab adalah kesanggupan seorang karyawan dalam menyelesaikan pekerjaan yang diserahkan kepadanya dengan baik, tepat waktu, serta berani mengambil resiko untuk keputusan yang dibuat atau tindakan yang dilakukan.

3. Pengabdian.

Pengabdian adalah sumbangan pemikiran dan tenaga secara ikhlas kepada perusahaan.

4. Kejujuran.

Kejujuran adalah keselarasan antara yang terucap atau perbuatan demgan kenyataan.

\section{Komitmen Organisasi}

Komitmen adalah sikap atau perasaan kesetiaan pada seseorang atau kelompok yang dirasakan sebagai kewajiban dan rasa cinta (Drever, 2006). Komitmen merupakan keinginan dari seseorang untuk memberikan kemampuan, pengabdian, mengidentifikasi dan merasa dirinya menjadi bagian dari suatu organisasi ditunjukkan dengan keinginan

untuk bekerja dan berusaha sebaik-baiknya dan untuk mempertahankan keanggotaannya dalam organiasai itu dan membantu mewujudkan tujuan dari organisasi. Komitmen organisasi didefenisikan sebagai keberpihakan seorang karyawan terhadap organisasi tertentu serta tujuantujuan dan keinginannya untuk mempertahankan keanggotaan dalam organisasi tersebut. Porter, et al. (dalam Tobing, 2009) mendefinisikomitmen organisasional sebagai kekuatan relatif individu terhadap suatu organisasi dan keterlibatannya dalam organisasi tertentu, yang dicirikan oleh tiga faktor psikologis:

1. Keinginan yang kuat untuk tetap menjadi anggota organisasi tertentu

2. Keinginan untuk berusaha sekuat tenaga demi organisasi, dan

3. Kepercayaan yang pasti dan penerimaan terhadap nilai-nilai dan tujuan organisasi.

Komitmen organisasi berhubungan dengan perasaan dan keyakinan karyawan tentang organisasi tempat dia bekerja secara keseluruhan. Menurut George danJones (2012:187), ada dua dimensi komitmen organisasi yaitu:

1. Komitmen efektif, yaitu komitmen pada saat karyawan tersebut masuk menjadi anggota suatu organisasi, senang, percaya, dan merasa baik berada di organisasi tersebut dan akan melakukan yang terbaik untuk organisasi.

2. Komitmen yang kedua yaitu komitmen continuance, ketika karyawan sudah tidak memiliki komitmen dan keinginan yang besar untuk berada disuatu organisasi tetapi mereka memikirkan penghasilan yang ditinggalkan terlalu besar seperti (kehilangan senioritas, keamanan kerja, pensiun, tunjangan kesehatan, dan sebagainya).

\section{METODOLOGI PENELITIAN}

\section{Jenis Penelitian dan Pengumpulan Data}

Penelitian ini merupakan explanatory research yang menjelaskan hubungan kausal atau sebab akibat. Metode pengumpulan data yang digunakan yaitu instrumen kuesioner dengan tipe pertanyaan tertutup.

\section{Populasi dan Sampel}

Populasi yang digunakan pada penelitian ini yaitu seluruh karyawan PT. Astra Honda Motor Cabang Masamba berjumlah 35 orang. Penentuan jumlah sampel dilakukan dengan menggunakan teknik sensus yaitu dengan menjadikan seluruh populasi sebagai sampel penelitian yaitu berjumlah 35 sampel.

\section{Analisis Data}

Metode analisis data yang digunakan pada penelitian ini yaitu analisis regresi linier berganda. Sebelum melakukan analisis regresi linier berganda terlebih dahulu dilakukan tahap uji validitas dan reliabilitas. 


\section{HASIL PENELITIAN}

1. Uji Validitas dan Reliabilitas

Berdasarkan hasil uji validitas untuk konstruk loyalitas, komitmen organisasi, dan kinerja karyawan tersaji pada tabel 1.

Tabel 1. Hasil Uji Validitas Konstruk Loyalitas, Komitmen Organisasi, dan Kinerja Karyawan

\begin{tabular}{|c|c|c|c|c|}
\hline Variabel & Pernyataan & r Hitung & r Tabel & Hasil \\
\hline \multirow{4}{*}{ Loyalitas } & $\mathrm{X} 1.1$ & 0,704 & 0,333 & Valid \\
\cline { 2 - 5 } & $\mathrm{X} 1.2$ & 0,694 & 0,333 & Valid \\
\cline { 2 - 5 } & $\mathrm{X} 1.3$ & 0,682 & 0,333 & Valid \\
\cline { 2 - 5 } & $\mathrm{X} 1.4$ & 0,779 & 0,333 & Valid \\
\hline \multirow{3}{*}{$\begin{array}{c}\text { Komitmen } \\
\text { Organisasi }\end{array}$} & $\mathrm{X} 2.1$ & 0,574 & 0,333 & Valid \\
\cline { 2 - 5 } & $\mathrm{X} 2.2$ & 0,541 & 0,333 & Valid \\
\cline { 2 - 5 } & $\mathrm{X} 2.3$ & 0,617 & 0,333 & Valid \\
\cline { 2 - 5 } Kinerja & $\mathrm{X} 2.4$ & 0,649 & 0,333 & Valid \\
\cline { 2 - 5 } Karyawan & $\mathrm{Y} .1$ & 0,775 & 0,333 & Valid \\
\cline { 2 - 5 } & $\mathrm{Y} .2$ & 0,563 & 0,333 & Valid \\
\cline { 2 - 5 } & $\mathrm{Y} .3$ & 0,678 & 0,333 & Valid \\
\cline { 2 - 5 } & $\mathrm{Y} .4$ & 0,563 & 0,333 & Valid \\
\cline { 2 - 5 } & $\mathrm{Y} .5$ & 0,763 & 0,333 & Valid \\
\hline
\end{tabular}

Sumber: data hasil pengolahan peneliti, 2020

Berdasarkan informasi hasil pengujian validitas pada tabel 1 , bahwa untuk konstruk loyalitas dengan empat item pernyataan $(\mathrm{X} 1.1, \mathrm{X} 1.2, \mathrm{X} 1.3$, dan X1.4) terkategori valid dengan nilai $\mathrm{r}$ hitung > $\mathrm{r}$ tabel. Konstruk komitmen organisasi dengan empat item pernyataan (X2.1, X2.2, X2.3, dan X2.4) terkategori valid dengan nilai $r$ hitung $>r$ tabel. Konstruk kinerja karyawan dengan lima item pernyataan (X3.1, X3.2, X3.3, X3.4 dan X3.5) terkategori valid dengan nilai $r$ hitung > $r$ tabel. Hasil pengujian reliabilitas untuk konstruk loyalitas, komitmen organisasi, dan kinerja karyawan dapat disajikan pada tabel 2.

Tabel 2. Hasil Uji Reliabilitas Konstruk Loyalitas, Komitmen Organisasi, dan Kinerja Karyawan

\begin{tabular}{|c|c|c|}
\hline Variabel & Cronbach's Alpha & Hasil \\
\hline Loyalitas & 0,67 & Reliabel \\
\hline Komitmen Organisasi & 0,40 & Reliabel \\
\hline Kinerja Karyawan & 0,69 & Reliabel \\
\hline
\end{tabular}

Sumber: data hasil pengolahan peneliti, 2020

Berdasarkan informasi hasil pengujian validitas pada tabel 2, bahwa untuk konstruk loyalitas terkategori reliabel dengan nilai cronbach alpha sebesar $0.676>0.60$. Konstruk komitmen organisasi terkategori reliabel dengan nilai cronbach alpha sebesar 0.40. Walaupun nilai ini lebih kecil dari 0.60 namun ini masih terkategori cukup (Fleiss, 1981).

\section{Nilai Koefisien Determinasi}

Hasil analisis diperoleh informasi untuk nilai koefisien determinasi (Adjusted $R$ Square) tersaji pada tabel 3 . 
Tabel 3. Nilai Koefisien Determinasi

\begin{tabular}{|l|r|r|r|r|}
\hline \multicolumn{5}{|c|}{ Model Summary } \\
\hline Model & $\mathrm{R}$ & R Square & Adjusted R Square & \multicolumn{1}{|c|}{$\begin{array}{c}\text { Std. Error of the } \\
\text { Estimate }\end{array}$} \\
\hline 1 &, $464^{\mathrm{a}}$ &, 215 &, 166 & 1,829 \\
\hline
\end{tabular}

Sumber: data hasil pengolahan peneliti, 2020

Berdasarkan informasi pada tabel 3, diketahui nilai Adjusted R Square sebesar 0.166 (16.6\%), hal ini mengandung arti bahwa pengaruh variabel loyalitas dan Komitmen Organisasi secara simultan terhadap variabel kinerja karyawan adalah sebesar 16.6\%. Sedangkan sisahnya $83.4 \%$ dijelaskan oleh factor lain yang tidak dijelaskan dalam penelitian ini.

\section{Analisis Regresi Linier Berganda}

Hasil analisis regresi linier berganda untuk pengaruh loyalitas dan komitmen organisasi terhadap kinerja karyawan tersaji pada tabel 4.

Tabel 4. Hasil Uji Analisis Regresi Linier Berganda

\begin{tabular}{|c|c|c|c|c|c|c|}
\hline \multicolumn{7}{|c|}{ Coefficients $^{\mathbf{a}}$} \\
\hline \multirow{2}{*}{\multicolumn{2}{|c|}{ Model }} & \multicolumn{2}{|c|}{$\begin{array}{c}\text { Unstandardized } \\
\text { Coefficients }\end{array}$} & \multirow{2}{*}{$\begin{array}{c}\text { Standardized } \\
\text { Coefficients }\end{array}$} & \multirow[t]{2}{*}{$\mathrm{T}$} & \multirow[t]{2}{*}{ Sig. } \\
\hline & & B & Std. Error & & & \\
\hline \multirow{3}{*}{1} & (Constant) & 12,802 & 3,787 & & 3,381 & , 002 \\
\hline & Loyalitas & ,615 & ,210 & ,496 & 2,933 & ,006 \\
\hline & $\begin{array}{l}\text { Komitmen } \\
\text { Organisasi }\end{array}$ &,- 137 & , 195 &,- 119 &,- 702 & , 488 \\
\hline
\end{tabular}

Sumber: data hasil pengolahan peneliti, 2020

Berdasarkan tabel 4, maka dapat disusun persamaan regresi yaitu:

$\mathrm{Y}=12.802+0.615$ Loyalitas -0.137 Komitmen Organisasi

Interpretasi dari persamaan diatas sebagai berikut:

1. Nilai konstanta sebesar 12.802 dapat diinterprestasikan bahwa apabila variabel loyalitas, dan variabel komitmen organisasi adalah constant (tidak berubah) maka keputusan Kinerja karyawan adalah 12.802 .

2. Koefisien regresi loyalitas sebesar 0.615 dapat diinterprestasikan bahwa variabel loyalitas mempengaruhi kinerja karyawan sebesar 0.615 , artinya apabila setiap peningkatan variabel satu satuan maka akan meningkatkan kinerja karyawan sebesar 0.615 .

Koefisien regresi komitmen organisasi sebesar $(-0,137)$ dapat diinterprestasikan bahwa variabel komitmen organisasi mempengaruhi kinerja karyawan sebesar -0.137 , artinya apabila setiap peningkatan variabel satu satuan maka akan menurunkan kinerja karyawan sebesar 0,137.

\section{PEMBAHASAN}

\section{Pengaruh loyalitas terhadap kinerja karyawan}

Hasil penelitian ini menunjukkan bahwa Loyalitas berpengaruh signifikan terhadap kinerja karyawan. Hal ini dibuktikan bahwa variabel loyalitas dengan signifikan sebesar 0,006 menunjukkan bahwa nilai tersebut lebih kecil dari 0,05 $(0,006<0,05)$, maka $\mathrm{H}_{1}$ diterima dan $\mathrm{H}_{0}$ ditolak. Nilai $\mathrm{t}_{\text {hitung }} 2,933>\mathrm{t}_{\text {tabel }} 2,036$, dapat disimpulkan bahwa variabel loyalitas, memiliki konstribusi terhadap variabel Kinerja Karyawan. Nilai t positif, hal ini menunjukkan bahwa Loyalitas searah dengan Kinerja Karyawan. Loyalitas merupakan kesetiaan karyawan pada perusahaan tempatnya bekerja. Bagi perusahaan memperkerjakan karyawan yang memiliki loyalitas tinggi sangatlah menguntungkan. Penelitian ini sejalan dengan penelitian Yulianthini (2016); Ariyani, Aini, \& Tjahjono (2016); Mamesah, Kawet \& Lengkong (2016) yang menunjukkan bahwa adanya pengaruh signifikan antara loyalitas karyawan terhadap kinerja karyawan. 


\section{Pengaruh komitmen organisasi terhadap kinerja karyawan}

Hasil penelitian ini menunjukkan bahwa komitmen organisasi tidak berpengaruh signifikan terhadap Kinerja Karyawan. Hal ini di buktikan bahwa komitmen organisasi dengan signifikasi sebesar 0.488 menunjukkan bahwa nilai tersebut lebih besar dari $0.05(0.488>0.05)$. Maka $\mathrm{H}_{1}$ ditolak dan $\mathrm{H}_{0}$ diterima. Nilai $t_{\text {hitung }}(-0.702)<2.036$. Dapat disimpulkan bahwa variabel komitmen organisasi tidak berpengaruh terhadap variabel Kinerja Karyawan. Nilai t negatif menunjukkan bahwa komitmen organisasi berlawanan arah dengan kinerja karyawan. Hal ini disebabkan karena komitmen organisasi yang dimiliki karyawan belum sepenuhnya optimal jika diperhadapkan pada suatu masalah, apakah karyawan akan terus bekerja dengan status dalam perusahaan karyawan tidak tetap, dengan berbagai macam kekurangan dalam memenuhi kebutuhan sehingga karyawan kurang maksimal memberikan pelayanan terhadap konsumen, dan kurang diperhatikannya pendidikan terakhir dalam bekerja dan kepribadian. Dengan demikian semakin rendah Komitmen Organisasi maka semakin menurun Kinerja Karyawan. Penelitian ini sejalan dengan temuan peneliitan yang dilakukan Arizona, Riniwati, \& Harahap. (2013); Subejo, Troena, Thoyib, Aisjah (2013) menunjukan bahwa secara parsial komitmen organisasional tidak mempunyai pengaruh yang signifikan terhadap kinerja.

\section{KESIMPULAN}

Berdasarkan hasil dan pembahasan penelitian yang telah diuraikan dapat disipulkan bahwa dari dua konstruk yang mempengaruhi kinerja karyawan yaitu loyalitas dan komitmen organisasi secara parsial hanya ada satu yang dapat membutikan hipotesis yaitu variabel loyalitas. Konstruk komitmen organisasi tidak berpengaruh signifikan terhadap kinerja karyawan. Untuk peneliti selanjutnya direkomendasikan untuk menambah jumlah konstruk variabel bebas (misalnya insentif dan motivasi). Rekomendasi ini didasarkan pada nilai Adjusted $R$ Square yang dihasilkan pada model yang masih terkategori rendah.

\section{DAFTAR PUSTAKA}

Ariyani, R. I., Aini, Q., \& Tjahjono, H. K. (2016). Pengaruh Gaya Kepemimpinan dan Loyalitas Karyawan Terhadap Kinerja Karyawan di Rumah Sakit Islam Hidayatullah Yogyakarta. Jurnal Medicoeticoilegal dan Manajemen Rumah Sakit, 5(2), 1.

Arizona, D. D., Riniwati, H. H., \& Harahap, N. N. (2013). Analisis Pengaruh Gaya Kepemimpinan, Motivasi Kerja Dan Komitmen Organisasional Terhadap Kinerja Pegawai (Studi Pada Dinas Kelautan Dan Perikanan Kabupaten Malang). Jurnal Mahasiswa Agribisnis Perikanan, 1(1), 1-11.

Fleiss, J. L. (1981). Statistical methods for rates and proportions (2nd ed). New York: Wiley.

Kosasih, Y. S. (2014). Pengaruh budaya dan komitmen organisasional terhadap kinerja karyawan. Agora, 2(1), 665-673.

Lumingkewas, G. D., Adolfina, A., \& Uhing, Y. (2019). ANALISIS PENGARUH BUDAYA ORGANISASI DAN LOYALITAS TERHADAP KINERJA KARYAWAN BANK SULUT-GO KANTOR CABANG TOMOHON. Jurnal EMBA: Jurnal Riset Ekonomi, Manajemen, Bisnis dan Akuntansi, 7(3), 3269-3278.

Mamesah, A. M., Kawet, L., \& Lengkong, V. P. (2016). Pengaruh Lingkungan Kerja, Disiplin Kerja, dan Loyalitas Kerja Terhadap Kinerja Karyawan Pada LPP RRI Manado. Jurnal EMBA: Jurnal Riset Ekonomi, Manajemen, Bisnis dan Akuntansi, 4(3), 600-611.

Muis, M. R., Jufrizen, J., \& Fahmi, M. (2018). Pengaruh budaya organisasi dan komitmen organisasi terhadap kinerja karyawan. Jesya (Jurnal Ekonomi \& Ekonomi Syariah), 1(1), 925.

Nasution, M. I. (2017). Pengaruh Stres Kerja, Kepuasan Kerja Dan Komitmen Organisasi Terhadap Turnover Intention Medical Representative. MIX: Jurnal Ilmiah Manajemen. 7(3), 407-428.

Nathania, Y. (2018). Pengaruh Budaya Organisasi Dan Komitmen Organisasional Terhadap Kinerja Karyawan Pada Warunk Upnormal Surabaya. Agora, 6(1), 1-9. 
Onsardi, O. (2018). Loyalitas Karyawan pada Universitas Swasta di Kota Bengkulu. COSTING: Journal of Economic, Business and Accounting, 2(1), 1-13.

Saputra, A. T., Bagia, I. W., Yulianthini, N. N. (2016). Pengaruh kepuasan kerja dan loyalitas karyawan terhadap kinerja karyawan. Jurnal Manajemen Indonesia, 4(1), 1-8.

Subejo, E. A. T., Thoyib, A., \& Aisjah, S. (2013). The Effect of Organizational Commitment and Organization Identity Strength to Citizenship Behaviour (OCB) Impact On Fire Department and Disaster Employee Performance in Jakarta Indonesia. IOSR Journal of Business and Management (IOSR-JBM), 10(3), 30-36.

Tamba, A. W., Pio, R. J., \& Sambul, S. A. (2018). Pengaruh Disiplin Kerja Dan Loyalitas Karyawan Terhadap Kinerja Karyawan Pada PT. Columbindo Perdana Cabang Manado. JURNAL ADMINISTRASI BISNIS (JAB), 7(001), 33-41. 